\title{
Third World Women Representation in Western Feminist Discourse: A Critical Study
}

\author{
Fettah EL OUARDI \\ English Studies Department \\ Faculty of Letters and Human Sciences Dhar Mehraz Fes \\ University of Sidi Mohamed Ben Abdellah Fes, Morocco
}

\begin{abstract}
Kebir SANDY
English Studies Department

Faculty of Letters and Human Sciences Dhar Mehraz Fes

University of Sidi Mohamed Ben Abdellah Fes, Morocco
\end{abstract}

\begin{abstract}
The Western representation of others and particularly Third World women is not a recent fabrication but it had been operational and deep-rooted in the West conceptualization ever since the first encounters between Europe and its other. With this in mind, this paper purports to examine the representation/image of the female Other in the Eurocentric feminist narratives as well as to uncover the pitfalls that Western feminist scholars face while attempting-in their so-called mission - to rescue their sisters in the Third world societies. This paper counters the fallacy that has been long held by Western feminists about Third World women as being homogenous and 'uncivilized other'. Drawing on postcolonial feminist thought, this paper presents a critique of Western feminism vis-à-vis Third World feminism and literary contributions namely, Chadra Mohanty and Gayatri Spivak' theorizations.
\end{abstract}

Keywords: Chandra Mohanty, feminist western discourse, Gayatri Spivak, orientalism, representation, third world women, western feminism

Cites as: EL OUARDI, F., \& SANDY, K. (2019). Third World Women Representation in Western Feminist Discourse: A Critical Study. Arab World English Journal for Translation \& Literary Studies, 3 (1) 127-135 . DOI: http://dx.doi.org/10.24093/awejtls/vol3no1.10 